\title{
Constituting Democracy in Hong Kong Ten Years
}

On

Michael C. Davis

\section{(2) OpenEdition}

\section{Journals}

Édition électronique

URL : http://journals.openedition.org/chinaperspectives/1593

DOI : 10.4000/chinaperspectives. 1593

ISSN : 1996-4617

Éditeur

Centre d'étude français sur la Chine contemporaine

\section{Édition imprimée}

Date de publication : 15 avril 2007

ISSN : 2070-3449

Référence électronique

Michael C. Davis, «Constituting Democracy in Hong Kong Ten Years On », China Perspectives [En ligne], 2007/2 | 2007, mis en ligne le 08 avril 2008, consulté le 28 octobre 2019. URL : http://

journals.openedition.org/chinaperspectives/1593; DOI : 10.4000/chinaperspectives.1593

(c) All rights reserved 


\title{
Constituting Democracy
}

\section{in Hong Kong}

\author{
Ten Years on
}

$J$ ust a decade ago we witnessed the launch of one of the most extraordinary political adventures of the late twentieth century, the return of freewheeling capitalist Hong Kong to an allegedly communist China under China's notion of "one country, two systems"-making Hong Kong a Special Administrative Region of the People's Republic of China. This anniversary marks the anniversary of a number of other landmarks in Hong Kong history. Over two decades have passed since the signing of the 1984 Sino-British Joint Declaration for Hong Kong's return. And 17 years have passed since the 1990 enactment of the Hong Kong Basic Law ${ }^{(1)}$, passed on the heals of China's harsh crackdown and suppression of the 1989 demonstrations. This legislation of China's National People's Congress (NPC) has become the constitution of Hong Kong and charts the roadmap for Hong Kong's long-term democratic development. It also affords constitutional security for Hong Kong's promised high degree of autonomy, human rights, and the rule of law. On account of the guarantees in the Joint Declaration and the Basic Law countries around the world have entered into numerous international agreements with and about Hong Kong.

Less noticed than the tenth anniversary of the handover was the twentieth anniversary in 2005 of Hong Kong's democratisation process. Mainland officials and supporters are fond of emphasising that democratisation in Hong Kong must be gradual and orderly. With the first democratic election of legislators by 12 functional constituencies in 1985 and the introduction of 18 directly elected seats in 1991, Hong Kong may have the most gradual and orderly democratisation process in the world.

During this first decade since the handover the contradiction between the liberal human rights protections that are afforded in Hong Kong and continued non-democratic authoritarian rule has been evident, producing a series of political crises. In a liberal constitutional environment the absence of democracy has produced the very instability that pro-Beijing opponents of democracy seem to most fear. We have been left to assess the costs of running a free society under the thumb of China's authoritarian system. Will a system of direct Beijing control underpinned by a network of political influence by Beijing supporters continue to be the dominant form of politics in Hong Kong, or will the constitutional democratic order promised in the Joint Declaration and the Basic Law be permitted to emerge? The wisdom of a decade of experience may suggest the merits of the latter.

The first decade after the handover has witnessed a vibrant democracy movement in Hong Kong and equally vibrant Beijing resistance. Political parties have flourished and pro-democracy politicians have generally done well in local elections. Mass demonstrations supporting democracy and related human rights concerns have become a common feature of Hong Kong politics. Pro-Beijing attacks on democracy have likewise persisted and the flagship pro-Beijing political parties have continued to carry the banner of resistance to democratic reform. In this environment China's resistance to democratic development has become the central plank of Beijing's Hong Kong policy. Various official interpretations by Beijing have scotched any serious efforts at political reform, posing a fundamental challenge to the "one country, two systems" model. Will the promised democracy be achieved? Does Beijing's stance on democracy pose a risk to the constitutional order and related stability in Hong Kong?

The analysis in the sections that follow lays out the constitutional roadmap for democratisation in Hong Kong, considers Beijing's interpretations of the Basic Law's democracy requirements, assesses the Hong Kong Government's efforts at compliance with these dictates, and

1. Basic Law of the Hong Kong Special Administrative Region of the People's Republic of China, 4 April 1990, 29 ILM 1511 (1990) ("Basic Law"). See Johannes Chan and Lison Harris, eds. Hong Kong's Constitutional Debates, Hong Kong, University of Hong Kong Centre for Comparative and Public Law, 2005. 
considers the constitutional debate now ensuing over full realisation of China's constitutional commitment to full universal suffrage in Hong Kong. The urgency of China relaxing its grip on Hong Kong and allowing orderly political development has become apparent. A failure to allow an orderly path of democratic development, for a society clearly ready for democracy, may mean risks for both China and Hong Kong.

\section{The constitutional framework for democratic development}

To understand Hong Kong's democratic development it is important to consider the foundational democratic requirements spelled out in the Sino-British Joint Declaration and the Hong Kong Basic Law. The 1984 SinoBritish Joint Declaration embodies China's design of "one country, two systems" and signals the democratic road ahead. Regarding democracy it specifies that the legislature be chosen by elections and the Chief Executive by elections or local consultations held locally. When released in 1984 the Joint Declaration obviously aimed to promote confidence in Hong Kong's future. It promised an anxious Hong Kong a "high degree of autonomy," and "Hong Kong people ruling Hong Kong," under a liberal system of democracy, human rights and the rule of law. Hong Kong people were told to "put their hearts at ease ${ }^{(2) . "}$

Not only did the Joint Declaration seek to reassure Hong Kong but it also reached out to the international community. It is important to emphasise that the Joint Declaration is an international treaty ratified by both governments and registered with the United Nations as such. As part of a great effort to garner international support, the PRC spoke to foreign governments, encouraging their reliance on the "one country, two systems" framework. Foreign governments were asked to establish separate economic, social and cultural relations with Hong Kong and to recognise Hong Kong as a distinct customs and immigration territory. Unquestionably, this treaty internationalised the Hong Kong issue and encouraged subsequent international concern over Hong Kong's democratic development.

The Basic Law takes up the Joint Declaration's democratic commitments in Articles 45 and 68, supplemented by Annexes I and II respectively. These provisions allow full democracy to be instituted after 2007 through elections for both the Chief Executive and the Legislative
Council (hereinafter "Legco") ${ }^{(3)}$. Article 45 of the Basic Law provides:

The method for selecting the Chief Executive shall be specified in light of the actual situation ... in accordance with the principle of gradual and orderly progress. The ultimate aim is the selection of the Chief Executive by universal suffrage upon nomination by a broadly representative nominating committee in accordance with democratic procedures.

Triggering the current democratic reform debate, Basic Law, Annex I specifies election of the Chief Executive by a "broadly representative" election committee in the first two terms but provides in Annex I, Article 7 for potentially expanding the level of democracy, as follows:

7. If there is a need to amend the method for selecting the Chief Executives for the terms subsequent to the year 2007, such amendments must be made with the endorsement of a two-thirds majority of all the members of the Legislative Council and the consent of the Chief Executive, and they shall be reported to the Standing Committee of the National People's Congress for approval. "Universal suffrage" is the "ultimate aim" specified in both articles 45 and 68, for the Chief Executive and Legco respectively. Article 68 provides essentially the same procedures respecting Legco's electoral reform, except that there is no need for a nominating committee and the provision on changing the method in Annex II, Article III expressly requires only that proposed changes be reported to the Standing Committee of the NPC "for the record ${ }^{(4)}$." Under the formula specified in Basic Law Annex II the number of directly elected Legco seats has already expanded incrementally to the current 30 . There are also 30 members representing various functional constituencies-from business, social and professional groups. A government proposal to expand both functional and directly elected seats equally by five was defeated by the democrats in Legco in 2005. From this point forward this 30-30 formula will remain operative until the method is changed as specified.

2. Michael C. Davis, "Constitutionalism in Hong Kong: Politics Versus Economics," Journal of International Economic Law, 18 March 1997, p. 155

3. Basic Law, Articles 45 and 68 and Annexes I and II.

4. Annex II, part III provides, "With regard to the method for forming the Legislative Council ... and its procedures for voting on bills and motions after 2007, if there is a need to amend the provisions of this Annex, such amendments must be made with the endorsement of a two-thirds majority of all the members of the Council and the consent of the Chief Executive, and they shall be reported to the Standing Committee of the National People's Congress for the record." 


\section{Beijing intercedes}

Under severe public pressure for a faster pace of democracy, on 6 April 2004, the Standing Committee of the National People's Congress (NPCSC) moved to offer its own interpretation of the above noted Annex I, Article 7 and Annex II, Article III in relevant parts as follows:

The Chief Executive of the Hong Kong Special Administrative Region shall make a report to the Standing Committee of the National People's Congress as regards whether there is a need to make an amendment; and the Standing Committee of the National People's Congress shall, in accordance with the provisions of Articles 45 and 68 of the Basic Law..., make a determination in the light of the actual situation in the Hong Kong Special Administrative Region and in accordance with the principles of gradual and orderly progress. The bills on the amendments to the method for selecting the Chief Executive and the method of forming the Legislative Council and its procedures for voting on bills and motions and the proposed amendments to such bills shall be introduced by the Government ... into the Legislative Council ${ }^{(5)}$.

The interpretation effectively amounted to an amendment of the Basic Law. It gives the Chief Executive complete control of any initiation of democratic reform and the central government veto power. Procedurally this appears to contradict Article 159, which specifies its own method of Basic Law amendment, requiring approval by the full NPC and specifying that amendments not contravene the basic policies of the PRC listed in the Joint Declaration. The interpretation also appears to contradict the above noted Annex II, Article III specification that changes in the method of electing the Legco need only be reported to the NPC Standing Committee "for the record." The PRC government had not always taken the view that it could intervene so readily in this democratic reform decision. In a comment in the People's Daily on 18 March 1993, the then Director of the Hong Kong and Macau Affairs Office, Mr. Lu Ping, stated, "As for how the legislature will be constituted after its third term, all that is needed is for two-thirds of legislators to approve, the chief executive to give his consent, and then report to the Standing Committee of the NPC for the record. There is no need for Central Government approval. How Hong

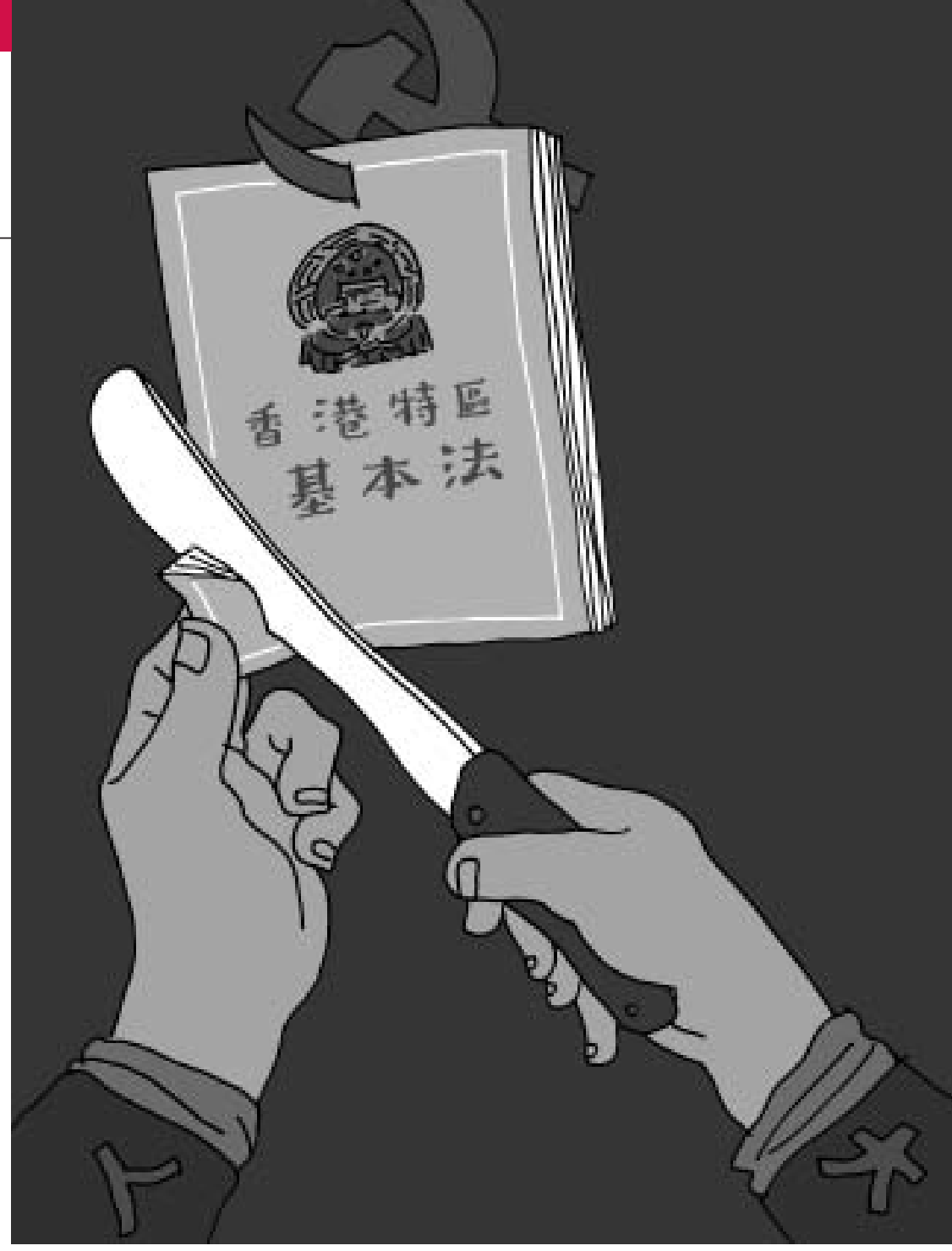

Kong develops democracy in the future is entirely within the autonomy of Hong Kong ${ }^{(6)}$." This statement from the leading Beijing official responsible for Hong Kong seemed to put the initiative and final decision for reforming the election of the Legco squarely on the local Hong Kong Government. Under the formula articulated in the interpretation, the Legislative Council can at best serve as a source of political pressure, perhaps by resolution, and approve or disapprove any final change to the methods of selection-an option the Legco embraced in rejecting the late 2005 government proposals.

Any doubts whether Beijing planned to use its newly found power to obstruct democracy were quickly dispelled. The 6 April interpretation was followed after just ten days by a report by a government task force on consti-

5. The Interpretation by the Standing Committee of the National People's Congress of Article 7 of Annex I and Article III of Annex II to the Basic Law of the Hong Kong Special Administrative Region of the People's Republic of China, Adopted by the Standing Committee of the Tenth National People's Congress at its Eighth Session on 6 April 2004, L.N. 54 of 2004 of the Hong Kong Gazette, L.S. No I2 to Gazette Ext. No. 5/2004, reproduced in Chan and Harris, supra note 2 ("6 April NPC Standing Committee interpretation"), paragraph 3.

6. Frank Ching, "Be Consistent," South China Morning Post, 30 March 2004 (pointing out this earlier statement). 
tutional reform. This was followed immediately by the Chief Executive's report specifying that there was a need to change the method for selecting the Chief Executive and forming the Legislative Council ${ }^{(7)}$. While specifying such need the Chief Executive's report added further obstacles to genuine change. It expressed concern about Hong Kong's political maturity and specified nine conditions that needed to be satisfied in determining democratic reform. By specifying how the "actual situation" would be evaluated, the Chief Executive's report appeared to add to the Basic Law requirements. Both reports emphasised the lack of political maturity of Hong Kong politicians and political groups, the need for different sectors of society to be represented (code for functional constituencies) and that "the pace should not be too fast." They also emphasised that changes should not have any adverse economic effect.

The NPC Standing Committee replied to the Chief Executive's Report on 26 April 2004, expressly prohibiting expansion of direct elections in 2007 and $2008^{(8)}$. In this decision, the Standing Committee specified that the Chief Executive must continue to be selected by the existing Election Committee in 2007-though the size of the Election Committee could be expanded-and that the ratio of directly elected to functional legislators must be maintained at the same 50-50 ratio for the 2008 Legco election ${ }^{(9)}$. This decision effectively prevented any serious democratic reform. The only reform options left open for the 2007-8 elections was to increase the size of the Election Committee and the Legco while essentially not advancing democratisation in relative or participatory terms. In October 2005 the Government put forth its reform proposal to double the Election Committee membership to 1,600 , with the bulk of such additions coming from members of the District Councils (both elected and appointed members), and adding five directly elected and five functional seats to Legco, with the functional seats all to be chosen by the District Council members ${ }^{(10)}$. The democratic camps raised an outcry and voted the proposals down in Legco, where a two-thirds vote was required ${ }^{(I I)}$.

\section{The 2007 constitutional de- bate and beyond}

Hong Kong is now at a new phase in its constitutional debate over democracy, anticipating elections for Legco and the Chief Executive in 2012. A government-appointed Commission on Strategic Development is preparing to issue its report on political reform in mid-summer 2007. This will be followed later in the year by a green paper and government consultation. Hong Kong is again witnessing the usual display of resistance to democratic reform from the pro-Beijing camp. This resistance is usually camouflaged in suggestions embodying obstacles to democratic participation that are argued to meet Basic Law requirements. The central objective appears to be to structure Legco to keep democrats in minority and to structure the nomination process for the Chief Executive in such a way as to block candidates from the democratic camp. The former usually involves efforts in Legco to preserve functional constituencies; the latter usually seeks to incorporate a mechanism to vet candidates for Chief Executive in the Nominating Committee required under the Basic Law.

Article 45 of the Basic Law, as noted above, specifies that, "The ultimate aim is selection of the Chief Executive by universal suffrage upon nomination by a broadly representative nominating committee in accordance with democratic procedures." Article 45 also gives Beijing the power to appoint any Chief Executive so chosen, a power that Beijing has long insisted is substantive-meaning they can also reject unacceptable candidates. If the threshold for nomination is not made too high, both democrats and pro-government forces tend to generally accept that the

7. The Second Report of the Constitutional Development Task Force, Issues of Principle in the Basic Law Relating to Constitutional Development, April 16, 2004, reproduced in Chan and Harris, supra note 2 ("Second Task Force Report"); Report on Whether There is a Need to Amend the Methods for Selecting the Chief Executive of the Hong Kong Special Administrative Region in 2007 and for Forming the Legislative Council of the Hong Kong Special Administrative Region in 2008, report of the Chief Executive, Hong Kong Special Administrative Region, Hong Kong, 15 April 2004, reproduced in Chan and Harris, supra note 2 (Chief Executive's Report).

8. Decision of the Standing Committee of the National People's Congress on Relevant Issues Concerning Methods for Selecting the HKSAR Chief Executive in 2007 and for Forming the Legislative Council in 2008, 26 April 2004, reproduced in Chan and Harris, supra note 2.

9. Note the 800-member Election Committee is chosen mostly by functional categories of electors representing commercial, professional and social interests. The existing categories have tended toward a pro-government and pro-Beijing orientation. The government can also count on the support of the vast majority of functional legislators.

10. The Fifth Report of the Constitutional Development Task Force, Package of Proposals for the Methods for Selecting the Chief Executive in 2007 and for Forming the Legislative Council in 2008, October 2005, www.cab.gov.hk/cd/text/eng/ report5/index.htm, accessed 7 March 2006, paras. 5.04 and 5.17 (Fifth Task Force Report). For the Election Committee to choose the Chief Executive, the Government recommended that 800 seats be added with approximately 500 including all members of the District Councils and the additional 300 seats coming from existing functional categories - with the details to be supplied later in a legislative amendment bill. For Legco, all five new functional seats were to be elected by the District Councils, with the method of this likewise to be determined in subsequent legislation. The proposals were rejected by Legco. 


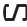

Nominating Committee can be based on the existing Election Committee, currently made up of functional members and existing legislators. Democrats see this not-so-representative committee as the path of least resistance, as long as it can produce a democratic candidate. The Election Committee has historically had a distinctly pro-Beijing bias. In the first two post-handover Chief Executive selections under the Election Committee only one pro-Beijing candidate could muster the 100 nominations needed and ran unopposed before the Election Committee. In the third such selection in 2007 the democratic camp made a concerted effort to secure enough nominations for Alan Leung of the Civic Party to run as a formal candidate. He could marshal only 132 nominations and 123 votes in the ultimate selection by the 800 -member Election Committee. Beijing's favoured candidate Donald Tsang not only won that selection but appeared to have strong support in public opinion polls. Instead of seeing in this the possibility of pro-Beijing candidates doing well in a popular election Beijing officials and pro-Beijing politicians have been shocked that the democratic candidate even secured nomination.

This Beijing anxiety has set the stage for the current critical constitutional debate over democratisation, the debate over the make-up and functioning of the Nominating Committee. The Beijing camp seems as determined as ever to block democrats from political power. The constitutional path to this objective under universal suffrage appears to be some mechanism in the required Nominating Committee to block pan-democratic candidates that are judged unacceptable to Beijing. Given statements of concern recently coming from the Beijing camp, the likelihood that some such nominating model to eliminate unacceptable democratic candidates will emerge from the Commission on Strategic Development or later in the process seems high. There is a similar likelihood that functional constituencies will be maintained.

A couple of models with a strong likelihood of blocking democrats from any popular Chief Executive election have already been devised. The pro-government Business and Professional Federation has put forth a proposal that would require that a nominee receive at least twenty nominations from each of the economic, professional, social and political sectors of the Nominating Committee (being one based on the Election Committee model)-given the committee make-up, a daunting challenge for democrats ${ }^{(12)}$. "Beijing sources" have noted that Beijing is taking a keen interest in this and have predicted an even more restrictive nominating process requiring the Nominating
Committee to make a "collective decision" on what candidates go forward to popular election ${ }^{(13)}$. This appears to signal support for a proposal already put forward by the Basic Law Institute whereby a candidate could be nominated by 50 nominators in the Nominating Committee but then the full Nominating Committee must select two favoured candidates to present to the public. The chance of a democrat clearing the latter process is slim.

Of course, there continues to be a debate over whether universal suffrage will be implemented at all-at least in the short term. In a recent seemingly unguarded moment, the Chair of the pro-Beijing DAB party, Ma Lik, caused a public outcry, when he argued that Hong Kong would not be ready for universal suffrage until 2022 because Hong Kong people lacked national identity. He based this conclusion on the refusal of Hong Kong people to accept Beijing's account of the 1989 massacre at Tiananmen, which he attributed to a lack of proper "national education ${ }^{(14)}$." As the opposition, the democratic camp continues to push for prompt democratisation. For democrats democratisation must at a minimum include a mechanism that can produce a democratic Chief Executive candidate for popular election and must include abolition of the Legco functional constituencies ${ }^{(15)}$.

The Hong Kong government has generally remained noncommittal on these issues. The government's Secretary for

11. K.C. Ng and Philip Pan, "Hong Kong Democrats Blast Reform Plan," Washington Post 13 0ctober 2005.

12. David Akers-Jones, "The Election Committee Should be the Basis for a Popular Election in 2012, Circle of Trust," South China Morning Post, 16 April 2007, A17.

13. Klaudia Lee, "Selection of CE Hopefuls Reviewed," South China Morning Post, 22 May 2007, A1.

14. Ambrose Leung, "HK Not Ready for Universal Suffrage Because of Unpatriotic View of June 4, says Ma Lik, Fury at DAB Chief's Tiananmen Tirade," South China Morning Post, 16 May 2007, A1.

15. The common characteristic of democratic camp proposals is a low nomination threshold for nomination in the Nominating Committee and abolition of functional constituencies. Twenty-one pan-democratic legislators have again put forth a proposal for universal suffrage by 2012 along these lines. National Democratic Institute, The Promise of Democratization in Hong Kong. The 2007 Chief Executive Election, NDI Hong Kong Report No. 11, 30 April 2007, at 17-18. A "core group" formed by the former Chief Secretary, Anson Chan envisions broadening the franchise of the 800 member Election Committee to form the Nominating Committee for Chief Executive, with a $10 \%$ threshold for nomination; and regrouping and broadening the functional constituencies for Legco into ten multi-seat constituencies for the coming 2008 election to be phased out in 2012, though her proposal allows some compromise to extend 15 regrouped (under three constituencies) functional seats for abolition before the 2016 election.. Ambrose Leung, et al., "Anson Chan Unveils Political Reform Road Map," South China Morning Post, 6 March 2007, A1; Ambrose Leung, et al., "Anson Chan Lays Down Her Vision for Trade-based Seats," South China Morning Post, 6 March 2007, A2.

16. Mr. Lam gave no clear indication of how the nominating committee might function Klaudia Lee, "Chief Executive Election 'Open to Democracy,'” South China Morning Post, 16 November 2003, 2. 
Constitutional Affairs, Stephen Lam, previously indicated that the government would not block democrats from running for Chief Executive ${ }^{(16)}$. Of course, running and actually having a chance at nomination are two different things. The Government now puts its hopes in the report of its Commission on Strategic Development due out this summer, from which a Green Paper will be compiled for public consultation. That Commission has seemingly ruled out vetting candidates for Chief Executive, but it is difficult to judge what exactly this means until its final report is out ${ }^{(17)}$. It has been reported that the Commission will put forth three electoral proposals for inclusion in the consultative Green Paper. One must wait to see if avenues for excluding democrats will come in under different strategies such as those suggested above. Secretary Stephen Lam has even tried to make the case that functional constituencies do not contradict the requirements of "universal suffrage ${ }^{(18) . "}$

Interpreting these constitutional requirements under the Hong Kong Basic Law will be the biggest constitutional challenge of the coming few years. Any failure to achieve genuine universal suffrage with popular access to the political process will surely be judged a failure of compliance with the Sino-British Joint Declaration and the Basic Law. In particular, a process of vetting or restricting top offices to a few unpopular Beijing supporters will surely result in continued public opposition and mass protest. If the experience of the past ten years is any indication such failure will also leave Hong Kong with a weak political system prone to crises and public confrontation. After one of the most "gradual and orderly" efforts at democratisation in history Hong Kong appears ready for a more mature fully democratic constitutional process. Meeting the challenges of the coming decade appears to greatly depend on adjustments in perspective and strong leadership in the Hong Kong and Beijing governments, as well as more mature democratic engagement by their supporters. Future Hong Kong leaders will surely be judged by their capacity to meet this constitutional challenge. 